\title{
Midwives' educational needs and knowledge about sexually transmittable infections in the Islamic Republic of Iran
}

Davoud Pourmarzi ${ }^{7}$ and Seyedeh Hajar Sharami ${ }^{2}$

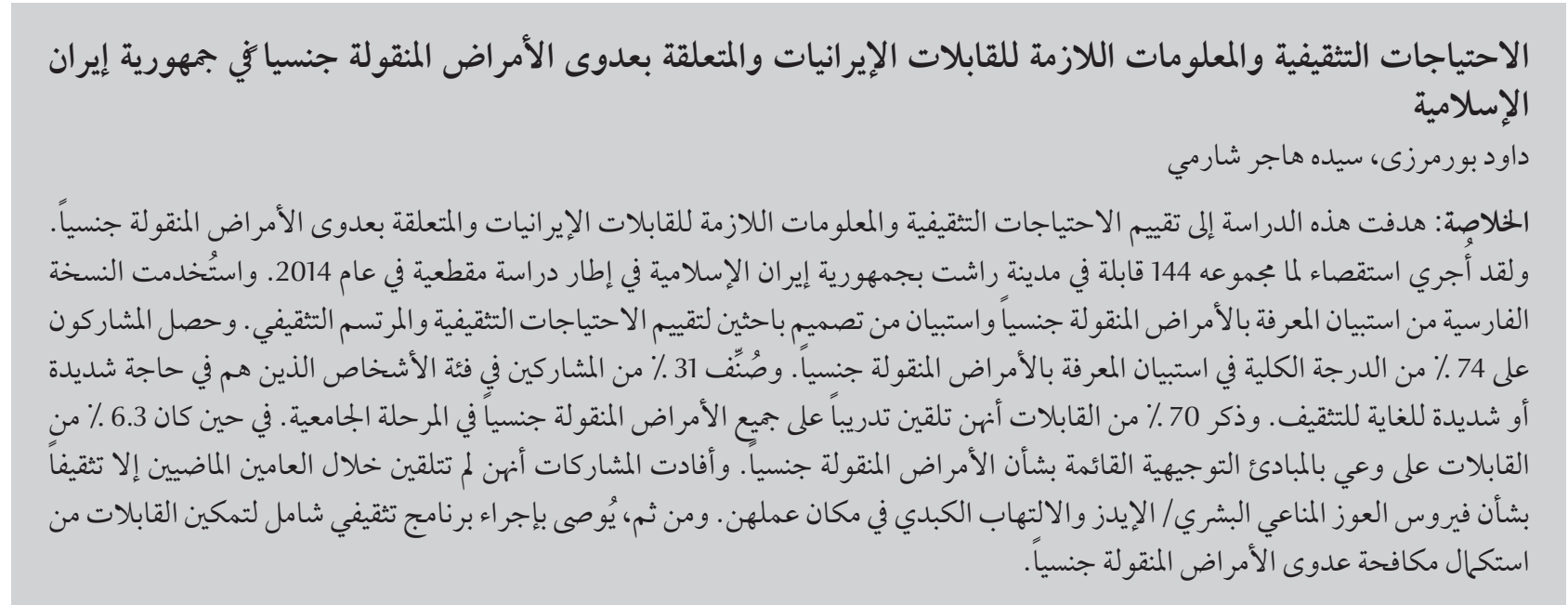

ABSTRACT This study aimed to evaluate the educational needs and knowledge about sexually transmittable infections (STIs) demonstrated by midwives. In a cross-sectional study in 2014, 144 midwives in Rasht, Islamic Republic of Iran, were surveyed. The Persian version of the Sexually Transmitted Disease Knowledge Questionnaire (STD-KQ) and a researcher-made questionnaire to evaluate educational needs and profile were used. The participants obtained $74 \%$ of the total score of STD-KQ. Thirty-one percent of participants were categorized in high or very high need of education. Seventy percent of midwives mentioned they were trained on all STIs at university. However, only $6.3 \%$ of midwives were aware of existing STIs guidelines. Participants reported that in the last two years they were only educated about HIV/AIDS and hepatitis B at their workplace. Thus, a comprehensive educational programme to empower midwives for complete STIs control is recommended.

\section{Besoins éducatifs et connaissances des sages-femmes iraniennes au sujet des infections sexuellement transmissibles en République islamique d'Iran}

RÉSUMÉ La présente étude avait pour objectif d'évaluer les besoins éducatifs et les connaissances des sagesfemmes iraniennes au sujet des infections sexuellement transmissibles. Lors d'une étude transversale réalisée en 2014, 144 sages-femmes ont fait l'objet d'une enquête à Rasht (République islamique d'Iran). La version perse du questionnaire sur les connaissances en matière d'infections sexuellement transmissibles ainsi qu'un questionnaire réalisé par un chercheur ont été utilisés afin d'évaluer les besoins et le profil éducatifs. Le score total au questionnaire sur les connaissances en matière d'infections sexuellement transmissibles obtenu par les participantes étaient de $74 \%$; 31 \% des participantes ont été classées comme ayant des besoins éducatifs importants voire très importants. Soixante-dix pour cent des sages-femmes ont mentionné qu'elle avaient été formées à la prise en charge de toutes les infections sexuellement transmissibles durant leurs études universitaires. Toutefois, seules 6,3\% d'entre elles connaissaient les directives existantes relatives aux infections sexuellement transmissibles. Les participantes ont signalé que durant les deux dernières années, elles n'avaient été formées que sur le VIH/sida et le virus de l'hépatite B sur leur lieu de travail. Par conséquent, un programme éducatif exhaustif est recommandé pour donner les moyens aux sages femmes de lutter contre toutes les infections sexuellement transmissibles.

${ }^{\top}$ Reproductive Health Research Centre, Guilan University of Medical Sciences, Rasht, Islamic Republic of Iran. (Correspondence to: Davoud Pourmarzi:Dpourmarzi@yahoo.com). 2Department of Obstetrics and Gynaecology, Reproductive Health Research Centre, Guilan University of Medical Sciences, Rasht, Islamic Republic of Iran

Received: 01/11/15; accepted: 16/01/17 


\section{Introduction}

Sexually transmitted infections (STIs) are a global public health problem. Worldwide, it is estimated that every day about 1 million people become infected (1). Valid data about the epidemiology of STIs in the Islamic Republic of Iran do not exist, but based on recent estimates, the incidence rates for Neisseria gonorrhoeae, Chlamydia trachoma, and syphilis per 1000 women are 2.44, 5.02 and 0.04 respectively; the corresponding figures per 1000 men are $0.43,0.82$ and 0.005 (2). STIs are more prevalent in developing countries, where infected people often do not receive appropriate and timely treatment. The control of STIs, especially in developing countries, cannot be successful without integrating it into the primary health care system $(2,3)$. The integration of STIs, HIV/AIDS, family planning, and mother and child health is emphasized by international health and development organizations (3).

However, there are many obstacles to controlling STIs in developing countries; some are related to the social environment and some to the weakness of the health care system $(1,2,4)$. Among the factors related to the health care system, the weak performance of health professionals in providing STI services has been highlighted $(1,4)$. In fact, health care providers in developing countries usually do not receive appropriate education about STIs (5-9).

To have a successful STI control programme, all involved staff should be adequately trained about STIs $(10,11)$. Midwives have an important role in STI control because they are a main source of information about these diseases and because they have a high interaction with women (12), who are more vulnerable to STIs and suffer more complications than men because of their genital system and gender-based inequalities (3). In addition, STIs can affect contraceptive effectiveness, fertility and pregnancy outcomes $(12,13)$. The integration of STIs in primary health care can provide the opportunity to detect and treat suspected STI cases in a timely fashion $(10,11)$.

An STI control programme is integrated in the Iranian primary health care system (14). However, continuing education for midwives in the workplace is necessary in order to have a successful STI control and prevention programme $(10,15)$. To design and provide an effective educational programme, the first step is to have information about midwives' knowledge of STIs and gaps where education is needed. However, this information is currently lacking. To the best of our knowledge, this is the first report about midwives' knowledge of STIs and their educational needs in the Islamic Republic of Iran. In previous studies, only health care providers' knowledge about HIV/AIDS and hepatitis $B$ were assessed $(5,9,16-20)$. In this study, we evaluated the knowledge of midwives in Rasht, Guilan Province, about STIs, their educational profiles and educational needs.

\section{Methods}

\section{Study design and sampling}

This was a cross-sectional study conducted from October to November 2014 among all midwives working in the Rasht health centre. The Rasht health centre is the only district health care centre in Rasht, the capital of Guilan province, northern Islamic Republic of Iran. The centre provides health care services for about 1 million inhabitants through 41 rural and urban health centres.

At the time of our study, 152 staff with a midwifery degree were working for the Rasht health centre; of these, 87 were midwives and 65 were family health care experts. During sampling, 144 midwives were recruited, 2 did not agree to participate and 6 were not present at the time of the study because of maternity or medical leave.

\section{Questionnaires}

Two questionnaires were used for data collection: the Sexually Transmitted Disease Knowledge Questionnaire (STD-KQ) (21), to evaluate the knowledge of the participants about STIs, and a questionnaire we designed to collect data about the educational profiles and needs of the midwives.

The STD-KQ contains 27 items (21). The Persian version was validated for use among health care providers in the Islamic Republic of Iran. The Cronbach alpha coefficient was 0.84 for overall STD-KQ (22). An STD-KQ item was excluded because of the unavailability of natural condoms in our country; hence, the Persian version of STD-KQ contains 26 items. Participants select true, false or do not know for each item. Correct answers were scored as 1 and incorrect or don't know were scored as 0 . Therefore, scores ranged from 0 to 26 .

Our questionnaire contained two parts. The first part included questions about the participant's demographic characteristics, and STI educational profile and work. The second part contained the names of 11 of the most prevalent STIs that were extracted from available regional data and a $\mathrm{WHO}$ report (23). The participants were asked to indicate their perceived educational need about each STI on a $1-5$ point Likert scale $(1=$ very low, 2 low, 3 = moderate, $4=$ high, 5 = very high). The scores for educational need ranged from 11 to 55. The overall score was categorized as: $11-19$, very low; 20-28, low; 29-37, moderate; 38-46, high; and $47-55$, very high.

To develop our questionnaire we used the opinions of 2 infectious diseases specialists, 1 gynaecologist, 2 epidemiologists and 2 midwives.

\section{Data collection}

During the study period, a co-worker went to the different health centres on different days and explained the study objectives to the participants and 
delivered the questionnaires to them at their workplaces. The participants were asked to fill out the questionnaire without any interference or assistance of others, place the completed questionnaire in an envelope and seal it. The questionnaire usually took 15 minutes to be filled out and the co-worker waited to collect the completed questionnaires.

\section{Ethical considerations}

The ethical committee of the Guilan University of Medical Sciences approved the study protocol. Informed verbal consent was obtained from each of the participants. All the participants were free to participant in this study and all questionnaires were anonymous; we used envelopes to assure participants' anonymity.

\section{Statistical analysis}

Data analysis was done using SPSS software, version 21.0. We had less than $3 \%$ missing data in some demographic (age) and work-related questions (location of work, years since graduation) which were imputed based on the other characteristics of the participants or data from other similar participants. To compare means among the groups, the independent $t$-test, one-way analysis of variance (ANOVA) and least significant difference post-hoc test were used. The Fisher exact test and chi-squared test were used to compare counts among the groups. In addition, the Pearson correlation coefficient was determined to assess the correlation between the perceived need for education score and STI knowledge score. $P<0.05$ was considered statistically significant.

\section{Results}

\section{Characteristics of the participants}

The mean age of the participants was 40.10 (SD 6.14) years (range 24-54). Most of the 144 participants had a bachelor degree (59.0\%), had more than 15 years work experience (57.6\%), had graduated more than 15 years before (56.3\%), were working as a midwife $(57.6 \%)$ and were working in an urban area $(69.4 \%)$ (Table 1).

\section{Education at the workplace and university}

Only 37 (25.7\%) and 33 (22.9\%) midwives had received training in HIV/ AIDS and hepatitis B respectively at their workplace in the past 2 years. As regards the other listed STIs, none of the participants had had any training at their workplace.

More than $70 \%$ of the midwives reported that they had received training on all of the listed STIs at university. However, the 2 STIs with the lowest percentage were granuloma inguinale (70.8\%) and chancroid (73.6\%). The majority of the midwives reported that educational material was available at the workplace on HIV/AIDS (68.8\%) and hepatitis B (66.7\%). However, less than $4 \%$ said educational materials were available for the other STIs. The majority of the midwives reported that they had read about HIV/AIDS (72.9\%) and hepatitis B (63.2\%) in the past year. Reading about granuloma inguinale and chancroid were reported by only $12.5 \%$ and $13.9 \%$ of the midwives respectively (Table 2).

\section{Preferred educational methods}

We asked participants to select one of the educational methods that we listed. Attending class was the most popular method for receiving training about STIs (61.1\%), followed by receiving printed educational material (22.2\%), seeing educational films (7.6\%), accessing educational websites (6.9\%) and receiving electronic educational materials (2.1\%). Only 9 of the midwives (6.3\%) were aware of existing STIs guidelines, only 4 (44.4\%) of whom had read them.

\section{STI knowledge}

The overall mean score for STD-KQ was 19.24 (SD 4.01) and the participants obtained about $74 \%$ of the total score of STD-KQ. The item that all midwives answered correctly was about

\begin{tabular}{lc}
\hline Table 1 Sociodemographic characteristics of the participants & \\
\hline Sociodemographic characteristic & No. $(\%)(\boldsymbol{n}=\mathbf{1 4 4})$ \\
Educational level & $59(41.0)$ \\
$\quad$ Associate degree & $85(59.0)$ \\
$\quad$ Bachelor degree & \\
Job title & $83(57.6)$ \\
$\quad$ Midwife & $61(42.4)$ \\
Family health expert & \\
Location of work & $44(30.6)$ \\
$\quad$ Rural & $100(69.4)$ \\
Urban & \\
Years since graduation & $15(10.4)$ \\
$\leq 5$ & $17(11.8)$ \\
$6-10$ & $31(21.5)$ \\
$11-14$ & $81(56.3)$ \\
$\geq 15$ & \\
Duration of work (years) & $13(9.0)$ \\
$\leq 5$ & $31(21.5)$ \\
$6-10$ & $17(11.8)$ \\
$11-14$ & $83(57.6)$ \\
$\geq 15$ &
\end{tabular}




\begin{tabular}{|c|c|c|c|}
\hline \multirow[t]{2}{*}{ STI } & $\begin{array}{l}\text { Received training at } \\
\text { university }\end{array}$ & $\begin{array}{l}\text { Educational material } \\
\text { available at the workplace }\end{array}$ & $\begin{array}{c}\text { Read about it in the current } \\
\text { year }\end{array}$ \\
\hline & No. (\%) & No. (\%) & No. (\%) \\
\hline HIV/AIDS & $125(86.8)$ & $99(68.8)$ & $105(72.9)$ \\
\hline Genital herpes & $127(88.2)$ & $3(2.1)$ & 39 (27.1) \\
\hline Genital warts & $122(84.7)$ & $3(2.1)$ & $35(24.3)$ \\
\hline Hepatitis B & 135 (93.8) & $96(66.7)$ & $91(63.2)$ \\
\hline Gonorrhoea & $123(85.4)$ & $2(1.4)$ & $26(18.1)$ \\
\hline Chlamydia & 119 (82.6) & $4(2.8)$ & $34(23.6)$ \\
\hline Syphilis & $122(84.7)$ & $3(2.1)$ & $30(20.8)$ \\
\hline Chancroid & $106(73.6)$ & $2(1.4)$ & $20(13.9)$ \\
\hline Granuloma inguinale & $102(70.8)$ & $2(1.4)$ & $18(12.5)$ \\
\hline Trychomoniasis & $133(92.4)$ & $4(2.8)$ & $68(47.2)$ \\
\hline Candidiasis & $133(92.4)$ & $5(3.5)$ & $72(50.0)$ \\
\hline
\end{tabular}

a vaccine for hepatitis B. Items that were answered correctly by less than $50 \%$ of the midwives were "A man must have vaginal sex to get genital warts” (27.8\%), "Frequent urinary infections can cause chlamydia" (47.2\%), "If a person tests positive for HIV, the test can tell how sick the person will become" (48.6\%), and "Having anal sex increases a person's risk of getting hepatitis B" (49.3\%) (Table 3).

\section{Education needs}

The overall mean score of reported need for education was 34.23 (SD 8.36), which was categorized as the moderate; $31.3 \%$ of the participants expressed a high or very high need for education. The 2 topics that the midwives felt they most needed education on were granuloma inguinale (3.51, SD 1.01) and chancroid (3.48, SD 0.98); 54.9\% and $54.8 \%$ of the midwives reported the need for education as high or very high respectively. The lowest reported need for education was on HIV/AIDS (2.70, SD 1.17), where only $25 \%$ of the participants reported a high or very high need for education (Table 4).

There was significant negative correlation between perceived need for education and knowledge score (STDKQ) score $(r=-0.186, P=0.026)$.
Midwives who had received HIV/ AIDS training in the workplace in the past 2 years reported a lower need for education about the disease (2.38, SD 1.21) than those who had not had such training (2.81, SD 1.14), but the difference was not statistically significant $(P$ $=0.051)$. The results were similar for hepatitis B (2.64, SD 1.25; 2.99 SD 1.01, $P=0.097)$.

Having training at university did not have an effect on the reported need for education about STIs. However, reading about the listed STIs in the current year significantly reduced the perceived need for education about chlamydia $(P$ $=0.012)$, syphilis $(P=0.040)$, chancroid $(P=0.002)$ and granuloma inguinale $(P$ $=0.005)($ Table 5$)$.

\section{Discussion}

Based on our findings, midwives need training on STIs because they are not well informed about these diseases. Midwives at their workplace usually do not receive educational courses and materials about STIs except HIV/ AIDS and hepatitis B but not on such STIs as granuloma inguinale and chancroid which are endemic in the Islamic Republic of Iran.
Worldwide, HIV/AIDS is one of the most common STI; therefore, it is reasonable that it is highlighted in health care systems. The importance of HIV/ AIDS makes it a priority to have educational programmes $(1,24)$. Hepatitis B is also a common disease in our country and so it is a targeted disease for control within the Iranian population (25).

In addition, hepatitis $B$ vaccination is routine in health centres in our country (26). These facts may affect health care professionals' perceived educational needs and knowledge. All midwives in our study were working for health centres where hepatitis $B$ vaccination is routine. To improve staff knowledge about a disease that is targeted for control, health centres usually provide educational programmes and material about it. On the other hand, although granuloma inguinale and chancroid are uncommon diseases worldwide, both are endemic in the Islamic Republic of Iran (27). Despite the integration of STI control and prevention within the Iranian health care system, usually Iranian health care professionals are not well educated about these 2 and other STIs $(5,9,16-20,28)$.

Previous studies in the Islamic Republic of Iran have been conducted to evaluate health care professionals' 


\begin{tabular}{|c|c|}
\hline Item & $\begin{array}{l}\text { Correct answer No. } \\
(\%)\end{array}$ \\
\hline 1. Genital herpes is caused by the same virus as HIV & $129(89.6)$ \\
\hline 2. Frequent urinary infections can cause chlamydia & $68(47.2)$ \\
\hline 3. There is a cure for gonorrhoea & $102(70.8)$ \\
\hline 4. It is easier to get HIV if a person has another STI & $95(66.0)$ \\
\hline 5. Human papillomavirus is caused by the same virus that causes HIV & $105(72.9)$ \\
\hline 6. Having anal sex increases a person's risk of getting hepatitis B & $71(49.3)$ \\
\hline 7. Soon after infection with HIV a person develops open sores on his or her genitals (penis or vagina) & $124(86.1)$ \\
\hline 8. There is a cure for chlamydia & $123(85.4)$ \\
\hline 9. A woman who has genital herpes can pass the infection to her baby during childbirth & $111(77.1)$ \\
\hline 10. A woman can look at her body and tell if she has gonorrhoea & $136(94.4)$ \\
\hline 11. The same virus causes all of the STIs & $129(89.6)$ \\
\hline 12. Human papillomavirus can cause genital warts & $122(84.7)$ \\
\hline 13. Human papillomavirus can lead to cancer in women & $110(76.4)$ \\
\hline 14. A man must have vaginal sex to get genital warts & $40(27.8)$ \\
\hline 15. STIs can lead to health problems that are usually more serious for men than women & $90(62.5)$ \\
\hline 16. A woman can tell that she has chlamydia if she has a bad smelling odour from her vagina & $80(55.6)$ \\
\hline 17. If a person tests positive for HIV, the test can tell how sick the person will become & $70(48.6)$ \\
\hline 18. There is a vaccine to prevent a person from getting gonorrhoea & $117(81.3)$ \\
\hline 19. A woman can tell by the way her body feels if she has an STI & $120(83.3)$ \\
\hline $\begin{array}{l}\text { 20. A person who has genital herpes must have open sores to give the infection to his or her sexual } \\
\text { partner }\end{array}$ & $84(58.3)$ \\
\hline 21. There is a vaccine that prevents a person from getting chlamydia & $126(87.5)$ \\
\hline 22. A man can tell by the way his body feels if he has hepatitis B & $134(93.1)$ \\
\hline 23. If a person had gonorrhoea in the past, he or she is immune (protected) from getting it again & $126(87.5)$ \\
\hline 24. Human papillomavirus can cause HIV & $96(66.7)$ \\
\hline 25. A man can protect himself from getting genital warts by washing his genitals after sex & $118(81.9)$ \\
\hline 26. There is a vaccine that can protect a person from getting hepatitis B & $144(100.0)$ \\
\hline
\end{tabular}

Table 4 Perceived need for education about sexually transmitted infections (STIs) among the midwives

\begin{tabular}{|c|c|c|c|c|c|c|}
\hline \multirow[t]{2}{*}{ STI } & Very low need & Low need & $\begin{array}{c}\text { Moderate } \\
\text { need }\end{array}$ & High need & $\begin{array}{l}\text { Very high } \\
\text { need }\end{array}$ & $\begin{array}{l}\text { Mean score } \\
\text { (SD) }\end{array}$ \\
\hline & No. (\%) & No. (\%) & No. (\%) & No. (\%) & No. (\%) & \\
\hline HIV/AIDS & $27(18.8)$ & $35(24.3)$ & $46(31.9)$ & $26(18.1)$ & $10(6.9)$ & $2.70(1.17)$ \\
\hline Genital herpes & $10(6.9)$ & $17(11.8)$ & $63(43.8)$ & $41(28.5)$ & $13(9.0)$ & $3.21(1.0)$ \\
\hline Genital warts & $10(6.9)$ & $18(12.5)$ & $66(45.8)$ & $38(26.4)$ & $12(8.3)$ & $3.17(0.99)$ \\
\hline Hepatitis B & 15 (10.4) & $35(24.3)$ & $52(36.1)$ & $32(22.2)$ & $10(6.9)$ & $2.91(1.08)$ \\
\hline Gonorrhoea & $5(3.5)$ & $23(16.0)$ & $50(34.7)$ & $52(36.1)$ & $14(9.7)$ & $3.33(0.97)$ \\
\hline Chlamydia & $11(7.6)$ & $26(18.1)$ & $56(38.9)$ & $41(28.5)$ & $10(6.9)$ & $3.09(1.02)$ \\
\hline Syphilis & $4(2.8)$ & $18(12.5)$ & $60(41.7)$ & $50(34.7)$ & $12(8.3)$ & $3.33(0.90)$ \\
\hline Chancroid & $7(4.9)$ & $13(9.0)$ & $45(31.3)$ & $62(43.1)$ & $17(11.8)$ & $3.48(0.98)$ \\
\hline Granuloma inguinale & $6(4.2)$ & $15(10.4)$ & 44 (30.6) & $57(39.6)$ & $22(15.3)$ & $3.51(1.01)$ \\
\hline Trychomoniasis & $27(18.8)$ & $32(22.2)$ & $43(29.9)$ & $30(20.8)$ & $12(8.3)$ & $2.78(1.21)$ \\
\hline Candidiasis & $30(20.8)$ & $31(21.5)$ & 43 (29.9) & $28(19.4)$ & $12(8.3)$ & $2.73(1.23)$ \\
\hline Total & $6(4.2)$ & $28(19.4)$ & $65(45.1)$ & $36(25.0)$ & $9(6.3)$ & $34.23(8.36)$ \\
\hline
\end{tabular}

$S D=$ standard deviation 


\begin{tabular}{|c|c|c|c|c|c|c|}
\hline \multicolumn{7}{|c|}{$\begin{array}{l}\text { Table } 5 \text { Perceived educational need about sexually transmitted infections (STIs) according to training received at universit } \\
\text { and reading during current year }\end{array}$} \\
\hline \multirow[t]{3}{*}{ STI } & \multirow{2}{*}{\multicolumn{2}{|c|}{$\begin{array}{l}\text { Perceived educational need } \\
\text { [Mean (SD)] } \\
\text { Received training on it at } \\
\text { university }\end{array}$}} & \multirow{3}{*}{$P$-value } & \multirow{2}{*}{\multicolumn{2}{|c|}{$\begin{array}{l}\text { Perceived educational need } \\
\text { [Mean (SD)] } \\
\text { Read about it in the current } \\
\text { year }\end{array}$}} & \multirow[t]{3}{*}{$P$-value } \\
\hline & & & & & & \\
\hline & No & Yes & & No & Yes & \\
\hline HIV/AIDS & $2.79(1.18)$ & $2.69(1.17)$ & 0.726 & $3.00(1.12)$ & 2.59 (1.17) & 0.062 \\
\hline Genital herpes & $3.12(1.05)$ & $3.22(1.0)$ & 0.693 & $3.27(1.01)$ & $3.05(0.97)$ & 0.253 \\
\hline Genital warts & 3.05 (1.05) & $3.19(0.98)$ & 0.534 & $3.26(0.98)$ & $2.89(0.96)$ & 0.053 \\
\hline Hepatitis B & $3.11(0.60)$ & $2.90(1.10)$ & 0.564 & $3.02(0.99)$ & $2.85(1.12)$ & 0.355 \\
\hline Gonorrhoea & $3.38(0.92)$ & $3.32(0.99)$ & 0.782 & $3.39(0.94)$ & 3.04 (1.08) & 0.096 \\
\hline Chlamydia & $3.32(0.95)$ & $3.04(1.04)$ & 0.218 & $3.21(1.01)$ & $2.71(1.00)$ & 0.012 \\
\hline Syphilis & $3.32(0.84)$ & $3.34(0.91)$ & 0.932 & $3.41(0.86)$ & $3.03(1.00)$ & 0.040 \\
\hline Chancroid & $3.47(1.11)$ & $3.48(0.94)$ & 0.968 & $3.58(0.93)$ & $2.85(1.09)$ & 0.002 \\
\hline Granuloma inguinale & $3.64(1.06)$ & $3.46(0.99)$ & 0.327 & $3.60(0.95)$ & $2.89(1.23)$ & 0.005 \\
\hline Trychomoniasis & $3.09(1.30)$ & $2.75(1.21)$ & 0.375 & $2.92(1.22)$ & $2.62(1.20)$ & 0.135 \\
\hline Candidiasis & $2.91(1.14)$ & $2.71(1.24)$ & 0.615 & $2.92(1.18)$ & $2.54(1.26)$ & 0.067 \\
\hline
\end{tabular}

$S D=$ standard deviation .

knowledge about HIV/AIDS and hepatitis B (5,9,16-20). These studies used their own questionnaire to evaluate participants' knowledge. Therefore, comparison with our findings has some limitations. Despite there being HIV/ AIDS and hepatitis B educational programmes, previous studies reported that Iranian health care providers had insufficient knowledge about them $(5,9,16-20)$. In a study conducted in Iranian health centres, only about $56 \%$ of health care providers had good knowledge about HIV/AIDS (5). In another study, about $50 \%$ of health care providers were aware of HIV transmission routes (16). A study on health care providers working in hospitals reported sufficient knowledge about HIV/AIDS transmission routes, treatment and preventions in only $59.3 \%, 52.1 \%$ and $52.9 \%$ of participants, respectively (19).

A study in Tehran, showed that less than $50 \%$ of nurses had sufficient knowledge about HIV/AIDS (17), while a study in Mashhad, north-east of Iran, found only $11 \%$ of midwives had sufficient skills to manage hepatitis B-infected pregnant women (18). Another study in Tehran, reported that only $11.7 \%$ of midwives and $8.3 \%$ of midwifery students had sufficient knowledge about hepatitis B (20). In a study that assessed educational needs of midwives working for health centres, STI education was reported a priority for midwives (8).

In a study in Peru, midwives answered about $63 \%$ of STI questions correctly (29), while a study in Indonesia showed midwives had moderate knowledge about HIV/AIDS (30). Ugandan midwives are reported to have a low knowledge about HIV (7), and about $30 \%$ of primary health care providers in Sri Lanka knew all methods of HIV transmission and $12 \%$ were aware of mother-to-child transmittable STIs (6). In Thailand, $54 \%$ of health care providers working in STIs services, had no STI training, and their knowledge about STI causes, transmission routes and symptoms was inadequate (31).

Based on our finding, only about $6 \%$ of midwives were aware of existing Iranian STI guidelines, $44.4 \%$ of whom had read them. This has an important impact on the effectiveness of the STI surveillance system. To have a high quality STI control programme, guidelines should be well designed and available for all STI service providers, and providers should be educated about the content and use of the guidelines (10).

In our study, the effect of having had training in the workplace about HIV/ AIDS and hepatitis B on perceived need for education was not significant. It can be concluded that the educational programme did not provide the midwives with sufficient knowledge. Many factors can affect the perceived need for education. It seems that educational content is important to meet the target groups' educational needs and so well designed programmes are needed to have a successful educational outcome (29).

Our findings showed that having training at university did not affect the reported need for education about STIs. However, reading about the listed STIs in the previous year significantly reduced the perceived need for education about some of the STIs. Education at university is for a finite time; therefore in the workplace, education should be continued. In our study, the majority of midwives had graduated more than 15 years before; after 15 years of last receiving education at university it would not be expected that there would be 
a reduction in the current perceived educational needs. Additionally, in the workplace, midwives encounter many issues that are not addressed at university; they therefore need to read about STIs to keep up-to-date $(12,32)$. In our study, reading about STIs in the current year illustrates the importance of providing educational materials to meet the needs of health care professions. Hence, a well designed continuous educational programme in the workplace for midwives is needed in order to have a successful STI control and prevention programme (12).

Using a self-administered questionnaire with lists of some of the prevalent STIs to assess educational needs may not show the actual need for education. However, conducting focus group discussions also has limitations; therefore, in this study we preferred to use a questionnaire to collect data about perceived educational needs. Another limitation of our study was the sample size, as we only recruited midwives working for health centres in the city of Rasht.

\section{Conclusion}

Based on our findings, midwives in Rasht are not adequately prepared to carry out STI prevention and control programmes in their workplace. Continuing and good quality educational programmes are needed for midwives to improve their knowledge. Policymakers should pay attention to the educational needs of midwives and recognize the important role this group of health care providers has in leading successful STI prevention and control programmes. Further studies to evaluate midwives' performance and skills for STI prevention and treatment are recommended.

\section{Acknowledgements}

We would like to thank the Vice-Chancellor for Research of Guilan University of Medical Sciences for supporting this project. We also thank the Vice-Chancellor for Health of Guilan University of Medical Sciences and the Rasht health centres for their kind collaboration. Finally, we thank all the midwives for their participation in our study.

Funding: Vice-Chancellor for Research of Guilan University of Medical Sciences.

Competing interests: None declared.

\section{References}

1. Sexually transmitted infections (STIs). Fact sheet No. 110. Geneva: World Health Organization; 2013.

2. Mayaud P, Mabey D. Approaches to the control of sexually transmitted infections in developing countries: old problems and modern challenges. Sex Transm Infect. 2004;80(3):17482.

3. Low N, Broutet N, Adu-Sarkodie Y, Barton P, Hossain M, Hawkes S. Global control of sexually transmitted infections. Lancet. 2006;368(9551):2001-16.

4. Mimiaga MJ, Reisner SL, Bland S, Skeer M, Cranston K, Isenberg D, et al. Health system and personal barriers resulting in decreased utilization of HIV and STD testing services among at-risk black men who have sex with men in Massachusetts. AIDS Patient Care STDS. 2009;23(10):825-35.

5. Meshkooti MHA, Mostaajeran M, Neamatolahi SH, Mohammadian B, Baadieyan GH, Hosseiny L. Knowledge and attitudes of health providers about AIDS, Esfahan 2011. Iranian Journal of Infectious Diseases and Tropical Medicine. 2013;18(60):47-51.

6. Ranathunga J, Somawardhana $\mathrm{H}$, Azraan A. Integration of $\mathrm{SRH} / \mathrm{STI} / \mathrm{HIV}$ services; Baseline assessment of knowledge in primary health care workers. Sri Lanka Journal of Venereology. 2013;3(1):38-40

7. Salyer JLH, Walusimbi ML, Fitzpatrick JJ. Knowledge and attitudes of Ugandan midwives regarding HIV. J Assoc Nurses AIDS Care. 2008;19(2):105-13.

8. Sereshti M, Banaean Sh, Delaram M, Kazemian A, Safdari F, Shamai Z. Educational needs of midwife alumni work in health care centers. Iranian Quarterly of Education Strategies. 2011;4(1):31-7.

9. Simbar M, Shayanmanesh M, Naheedi F. Knowledge, attitude and practice of midwives about HIV/AIDS prevention in selected hospital in Isfahan City, 2006. Pajoohandeh Journal. 2008;12(6):535-40.
10. Global strategy for the prevention and control of sexually transmitted infections: 2006-2015: breaking the chain of transmission. Geneva: World Health Organization; 2007.

11. Sexually transmitted diseases: policies and principles for prevention and care. Geneva: UNAIDS and World Health Organization; 1999.

12. Frontiers of midwifery care: STDs/HIV/AIDS in safe motherhood: report of a collaborative ICM/WHO/UNICEF/UNFPA/UNAIDS pre-congress workshop, Manila, Philippines, 19-22 May 1999. Geneva: World Health Organization; 2000 (http://apps.who.int/iris/bitstream/10665/66749/1/WHO_ RHR_99.20.pdf, accessed 21 June 2017).

13. Mullick S, Watson-Jones D, Beksinska M, Mabey D. Sexually transmitted infections in pregnancy: prevalence, impact on pregnancy outcomes, and approach to treatment in developing countries. Sex Transm Infect. 2005;81(4):294-302.

14. Khalili Gh, Feizzadeh A, Kamali K. Instruction of sexually transmitted infections surveillance in Iran. Tehran: Iran Center of Diseases Control and Prevention; 2006.

15. Forsetlund L, Bjørndal A, Rashidian A, Jamtvedt G, O'Brien MA, Wolf $\mathrm{F}$, et al. Continuing education meetings and workshops: effects on professional practice and health care outcomes. Cochrane Database Syst Rev. 2009;(2):CD003030

16. Jaafari FK, Falah N, Mahmoudpour A. Factors related to knowledge and attitude about AIDS. Daneshvar Medicine. 2007;14(68):1-8.

17. Zeighami Mohammadi S, Zeinali E. [Study on knowledge and attitude of internal and infectious wards nurses toward AIDS]. Journal of Urmia Nursing and Midwifery Faculty. 2012;9(6):440-49 [In Farsi].

18. Mirzakhani K, Jahani Shorab N, Golmakani N, Tafazoli M, Ebrahimzadeh S. Evaluation of clinical evaluation of clinical skills in midwives graduated from Mashhad nursing and midwifery 
faculty and employed in Mashhad health care centers. Journal of Urmia Nursing and Midwifery Faculty. 2012;9(6):472-80.

19. Mohebi Nobandegani Z, Mobaraki A, Afrasiabi Far A, Moshfe A. Knowledge and attitudes of health personnel working in educational hospitals of Yasuj city regarding AIDS. Armagan-eDanesh-J Yasuj Univ Med Sci. 2003;8:47-53.

20. Pakgohar M, Granmayeh M, Babaie G, Nazari M. A survey on knowledge of midwives and midwifery students about hepatitis B. Hayat. 2003;9(4):27-33.

21. Jaworski BC, Carey MP. Development and psychometric evaluation of a self-administered questionnaire to measure knowledge of sexually transmitted diseases. AIDS Behav. 2007;11(4):557-74.

22. Pourmarzi D, Taromian S, Razi M, Esmailie-Hesari R. Validity and reliability of Persian version of sexuality transmitted diseases knowledge questionnaire in health care providers. East Mediterr Health J. 2016;22(8):596-602.

23. Global incidence and prevalence of selected curable sexually transmitted infections-2008. Geneva: World Health Organization; 2012.

24. Nasirian M, Baneshi MR, Kamali K, Haghdoost AA. Estimation of prevalence and Incidence of sexually transmitted infections in Iran: a model-based approach. J Res Health Sci. 2015;15(3):168-74.

25. 25. Tabatabaee $M$, Zahraei M, Ahmadnia H, Ghotbi H, Rahim F. Principles of disease prevention and surveillance. Tehran: Roheghalam; 2007.

26. Farzianpour F, Bamdad Mehrabani K, Fadaei Dehcheshmeh $\mathrm{N}$, Azmal M. Evaluation of comparative management of ex- panded program immunization for children in Iran and in the world. Health. 2014;6(19):2697.

27. Berger S. Less common venereal diseases: global status. Los Angeles (CA): GIDEON Informatics Inc.; 2015.

28. Akbari N, Ramezankhani A, Pazargadi M. Accelerators/decelerators of achieving universal access to sexual and reproductive health services: a case study of the Iranian health system. BMC Health Serv Res. 2013;13(1):241.

29. Canchihuaman FA, Garcia PJ, Gloyd SS, Holmes KK. An interactive Internet-based continuing education course on sexually transmitted diseases for physicians and midwives in Peru. PLoS One. 2011;6(5):e19318

30. Liem A, Adiyanti MG. "Bidan cantik": Psychoeducation on HIV and AIDS to improve the service quality of midwives at Yogyakarta public health center. HIV \& AIDS Review. 2013;12(1):14-22.

31. Phrasisombath K, Thomsen S, Hagberg J, Sychareun V, Faxelid E. Knowledge about sexually transmitted infections (STIs) and attitudes toward female sex workers with STI symptoms among health care providers in Laos. Asia Pac J Public Health. 2012;24(6):940-52.

32. Njah M, Nouira A, Baati M, Ben AS, Mlika M. Profil de prise en charge des MST par les sages-femmes dans les consultations intégrées des centres de santé en Tunisie [Outline of the management of sexually transmitted diseases by midwives in integrated consultations in health centers in Tunisia]. Tunis Med. 2003;81(5):323-8. 